\title{
A TERCEIRIZAÇÃO DE SERVIÇO NA ADMINISTRAÇÃO PÚBLICA \\ ATRAVÉS DE CONVÊNIOS E A QUESTÃO DA ISONOMIA SALARIAL
}

\author{
THE OUTSOURCING OF THE SERVICES IN THE PUBLIC \\ ADMINISTRATION THROUGH THE PARTNERSHIP AND THE EQUAL PAY \\ ISSUE
}

Beches Vieira Junior ${ }^{1}$

\begin{abstract}
RESUMO: O presente trabalho analisa o instituto da terceirização de serviço na administração pública, dando ênfase, à forma de convênio, e à questão da isonomia salarial. Desta forma, poder-se-ia iniciar a discussão com a pergunta: deve haver isonomia salarial àqueles que efetivam serviço na administração pública, sem que haja efetivado concurso público, mas cedidos à administração através de convênios, quando em comparação ao servidor concursado? A resposta para tal indagação não é tão simples de se responder, e nem mesmo os Tribunais mostram uma só corrente em suas decisões respectivas. Há que se ter em mira, desde já, que a terceirização de serviços, não implica dizer terceirização de mão de obra, consoante será demonstrado. E este fator é determinante para a licitude das terceirizações no âmbito da administração pública.

Parte-se, portanto de uma abordagem acerca da terceirização de serviços, imbricado no instituto do convênio, mas antes se estabelecem conceitos importantes como 0 da própria administração pública, da terceirização propriamente dita, do histórico envolvendo este fenômeno tanto na esfera privada como na pública, chegando ao ponto crucial da questão da isonomina (ou não) salarial.
\end{abstract}

PALAVRAS-CHAVE: Terceirização. Administração Pública. Isonomia Salarial.

ABSTRACT: The current assignment analysis the institute of outsourcing of the service in the public administration, putting emphasis on the kind of partnership, and the matter of equal pay. Thus one would be able to start a discussion upon the question: should there be equal pay for those who carry out service in the public administration, not having those been taken public contest, however given in to the administration through the partnership, when being compared to the examined servant? The answer to such question isn't that simple to reply, and not even the court houses show only one single trend in the respective decisions. One should from this moment forth, bear in mind that the outsourcing of services, does not imply in saying work force outsourcing depending it will be shown. And this fact is crucial for the legality of the outsourcing in the public administration environment.

\footnotetext{
1 Mestre em Direitos Fundamentais e Democracia pela UNIBRASIL - Faculdades Integradas do Brasil/Curitiba. Especialista em Direito Processual Civil pelo Instituto de Direito Romeu Felipe Bacellar. Professor convidado pelo ICEET - Instituto de Ciência Educação e Tecnologia de Curitiba/PR.
} 
It all comes out from an approach about the outsourcing of the services situated in the Institute of partnership but first off it is stablished important concepts just like the public administration itself, the outsourcing itself the history involving this phenomena as much in the private environment as in the public one getting to the breakpoint of the matter of the equal (or not) pay.

KEY WORDS: Outsourcing, Public Administration, Equal Pay.

\section{INTRODUÇÃO}

O presente artigo traz à discussão assunto polêmico, que é o da terceirização de serviço no âmbito da administração pública, em especial quando da celebração de convênios, e os reflexos desta terceirização quando se remete a questão à isonomia salarial. Busca traçar lineamento para a justificação da contratação deste serviço terceirizado, bem como, entra na seara daquilo que é permitido legalmente e o que está em desequilíbrio e à margem da lei.

Em suma, apresenta-se a terceirização na administração pública, mas calcada na igualdade de tratamento entre os pares (concursados e contratados de forma terceirizada), sem que isto leve, necessariamente, ao entendimento de que a isonomia de tratamento deva necessariamente levar à isonomia de pagamento pecuniário. O tratamento igualitário é condição fundamental para um bom ambiente de trabalho. O princípio da igualdade é de tal envergadura que se constitui em verdadeiro alicerce para os demais direitos fundamentais. Não é sem razão que Jorge MIRANDA leciona que "os direitos fundamentais não podem ser estudados à margem da idéia de igualdade" 1 .

É oportuno frisar, desde já, que a Administração Pública não tem como suprir toda sua demanda de trabalho, senão com o labor, também, de terceiros. Assim, parte-se de algo que se mostra patente e necessário, que é justamente a necessidade de contratação do trabalhador não concursado para ingressar na Administração Pública, sem que com isto haja afronta ao artigo 37, II, da Constituição Federal, que assim se mostra:

Art. 37 - A administração pública direta e indireta de qualquer dos Poderes da

\footnotetext{
${ }^{1}$ MIRANDA, Jorge. Manual de Direito Constitucional, Tomo IV: Direitos Fundamentais, 2000, Coimbra: Coimbra, p. 201.
} 
União, dos Estados, do Distrito Federal e dos Municípios obedecerá aos princípios de legalidade, impessoalidade, moralidade, publicidade e eficiência e, também, ao seguinte:

(...)

II - a investidura em cargo ou emprego público depende de aprovação prévia em concurso público de provas ou de provas e títulos, de acordo com a natureza e a complexidade do cargo ou emprego, na forma prevista em lei, ressalvadas as nomeações para cargo em comissão declarado em lei de livre nomeação e exoneração;

(...)

Nesta seara, mostra-se imperiosa a definição do que venha a ser terceirização (em especial, de serviço), seu histórico, além da necessidade de adentrar no contexto de legislações pertinentes, como a de $n^{\circ} 8958 / 94$, que trata das relações entre as instituições federais de ensino superior e de pesquisa científica e tecnológica e as fundações de apoio, a de n 8666/93, que justamente vem a regulamentar o art. 37, inciso XXI, da Constituição Federal, instituindo normas para licitações e contratos da Administração Pública, a de $\mathrm{n}^{0}$ 8112/90, que dispõe sobre o regime jurídico dos servidores públicos civis da União, das autarquias e das fundações públicas federais, a de $n^{\circ} 8987 / 95$, que dispõe sobre o regime de concessão e permissão da prestação de serviços públicos previsto no art. 175 da Constituição Federal, o Decreto-lei de no 200/67, o Decreto 2.271/97, que Dispõe sobre a contratação de serviços pela Administração Pública Federal direta, autárquica e fundacional e dá outras providências, a Lei n $9527 / 97$, que altera dispositivos das Leis de números 8.112/90, 8.460/92, e 2.180/54, e dá outras providências. O Decreto-Lei 5452/43, a CLT - Consolidação das Leis do Trabalho -, entre outros dispositivos aplicáveis à espécie.

Após tais apontamentos, passa a tratar da terceirização através de convênios, mostrando sua legalidade, bem como, a impossibilidade de tratamento isonômico pecuniário. O ente parceiro, neste caso, e como se mostrará, estabelece uma relação de natureza administrativa (convênio), no qual se presume sua legalidade e legitimidade.

O artigo, assim, faz uma abordagem histórica da terceirização no Brasil, partindo-se, em especial, para o âmbito da Administração Pública, seus delineamentos, sua importância e necessidade, pois, como já frisado, há de se suprir a falta de mão de obra através da chamada terceirização, e aqui, registra-se em especial o convênio, entendendo este, evidentemente, como 
uma forma latu sensu de terceirização, e frise-se ainda mais, terceirização "de serviço", e não de mão de obra.

\section{DEFINIÇÃO DE TERCEIRIZAÇÃO DE SERVIÇOS E APONTAMENTOS HISTÓRICOS, EM ESPECIAL NA ADMINISTRAÇÃO PÚBLICA}

\subsection{A ADMINISTRAÇÃO PÚBLICA}

Antes mesmo da definição, bem como, de tecer comentários sobre aspectos históricos da terceirização no âmbito da administração pública, urge que se esclareça sucintamente o que vem a ser e o que abrange a administração pública, para que haja um perfeito posicionamento da matéria ora em questão.

Dentro do contexto de Administração Pública, pode-se afirmar ser o conjunto de agentes, serviços e órgãos instituídos pelo Estado com o objetivo de fazer a gestão de certas áreas, como Educação, Saúde, Cultura, entre outras.

Para o professor José Afonso da DA SILVA:

Administração Pública é o conjunto de meios institucionais, materiais, financeiros e humanos preordenados à execução das decisões políticas. Essa é uma noção simples de Administração Pública que destaca, em primeiro lugar, que é subordinada ao Poder Político; em segundo lugar, que é meio e, portanto, algo que se serve para atingir fins definidos e, em terceiro lugar, denota seus aspectos: um conjunto de órgãos a serviço do Poder Político e as operações, atividades administrativas².

A definição de Administração Pública, segundo Maria Sylvia Zanella DI PIETRO, pode ser dada em dois sentidos:

“a) em sentido subjetivo, formal ou orgânico, ele designa os entes que exercem a atividade administrativa; compreende pessoas jurídicas, órgãos e agentes públicos incumbidos de exercer uma das funções em que se triparte a atividade estatal: a função administrativa.

b) em sentido objetivo, material ou funcional, ele designa a natureza da atividade exercida pelos referidos entes; nesse sentido, a Administração Pública é a própria função administrativa que incumbe predominantemente, ao Poder Executivo"3.

2 DA SILVA, José Afonso. Curso de Direito Constitucional Positivo. 21. ed. São Paulo: Malheiros, 2002. p. 25.

${ }^{3}$ DI PIETRO, Maria Sylvia. Zanella. Direito administrativo. 25. ed. São Paulo: Atlas, 2012. p. 50. 
Márcio Fernando Elias ROSA faz uma abordagem, entre outros aspectos, sobre a Administração Pública em sentido material e em sentido subjetivo:

Administração Pública em sentido material: tange ao estudo da função administrativa (que difere da função legislativa e da função jurisdicional) e é típica para o Poder Executivo. Administração Pública em sentido subjetivo: tange ao estudo dos que devem exercer a função administrativa, as entidades públicas, seus órgãos e agentes ${ }^{4}$.

Marçal JUSTEN FILHO ao versar sobre Administração Pública, assim se manifesta 5 :

Utiliza-se, geralmente, a expressão Administração Pública para fazer referência ao conjunto de entes e organizações titulares da função administrativa. Mas a expressão pode ser interpretada em diversos sentidos. Numa expressão subjetiva, Administração Pública é uma espécie de atividade, caracterizada pela adoção de providências de diversa natureza, visando à satisfação imediata dos direitos fundamentais.

Voltado, ainda, ao aspecto da administração pública, e mesmo quando se fala em convênios, parcerias público-privadas, concessões, permissões, etc., não se pode olvidar de que, todo e qualquer ato deve estar calcado em princípios que norteiam a administração pública, em especial os ditado pelo artigo 37, caput, da Constituição Federal ${ }^{6}$.

Entre os princípios que regem a administração pública, está o princípio da moralidade, que, como ensina Bruno MIRAGEM, é pressuposto essencial da ação administrativa, informando que seu significado pressupõe o reconhecimento de que a Administração Pública possui um objeto, qual seja, o de realização do interesse público:

Dentre os princípios explícitos que informam a ação administrativa, com expressa referência na Constituição da República, está o princípio da

\footnotetext{
${ }^{4}$ ROSA, Márcio Fernando Elias. Direito Administrativo, Parte I, Coleção Sinopses Jurídicas, v. 19, Saraiva, 2010. p. 24.

${ }^{5}$ JUSTEN FILHO, Marçal. Curso de Direito Administrativo. 8. ed. rev. amp. e atual. Belo Horizonte: Fórum, 2012. p. 225-226.

${ }^{6}$ Art. 37. A administração pública direta e indireta de qualquer dos Poderes da União, dos Estados, do Distrito Federal e dos Municípios obedecerá aos princípios de legalidade, impessoalidade, moralidade, publicidade e eficiência (...).
} 
moralidade. Trata-se de princípio que traduz antiga preocupação presente na doutrina especializada, sobre a insuficiência da legalidade administrativa para justificar adequadamente todos os atos da Administração Pública. Neste sentido, mesmo quando não estava presente no sistema de direito positivo, possuía conteúdo normativo, como princípio implícito, e condicionava a ação da Administração Pública aos standards de comportamento ético que consagrava. Da mesma forma, seu significado pressupõe o reconhecimento de que a Administração Pública possui um objetivo, qual seja, o de realização do interesse público, e, neste sentido, toda ação administrativa que não se orienta neste propósito contraria a moralidade administrativa, considerada como conjunto de valores ético-jurídicos que imprimem o condicionamento da Administração Pública à sua finalidade? .

Também no que tange ao Princípio da Moralidade, assim se posiciona Helly Lopes MEIRELES:

A moralidade administrativa constitui, hoje em dia, pressuposto de validade de todo ato da Administração Pública (CF, art. 37, caput) ${ }^{8}$.

Desta forma, e tendo como alicerce da construção de qualquer ato administrativo o fato dele estar calcado e norteado por princípios constitucionais, estes elencados junto ao artigo 37, caput, as chamadas terceirizações devem, seguramente, caminhar no contexto da legalidade, o que inclui estar também em conformidade com a questão principiológica.

\subsection{DA TERCEIRIZAÇÃO}

O fenômeno da terceirização, segundo ensina Erico Ferrari NOGUEIRA, teve seus primeiros sinais durante a Segunda Guerra Mundial, período que a necessidade de se ocupar a mão de obra ociosa fez brotar o fenômeno ora estudado, bem como, enfatiza a necessidade de, num mundo globalizado e que clama por inovações, buscar a terceirização.

A história mostra que os primeiros sinais da terceirização sugiram durante a Segunda Guerra Mundial, período no qual, em razão da recessão existente, houve a necessidade de se buscar um sistema capaz de proporcionar a

\footnotetext{
${ }^{7}$ MIRAGEM, Bruno. A Nova Administração Pública e o Direito Administrativo. 2. ed. rev. e atual. São Paulo: Revista dos Tribunais, 2013, p. 227.

${ }^{8}$ MEIRELLES, Hely Lopes. Direito Administrativo Brasileiro. 27 ed. São Paulo: Malheiros, 2002. p. 87.
} 
ocupação da mão de obra ocioso, resultando na competitividade que culminou na redução de custos sem perda de qualidade.

Esse procedimento, focado na parceria e inovador naquela época, é hoje um dos mais utilizados, pois se apresenta como solucionador de problemas organizacionais no tocante à prestação de serviços de fornecimento de mão de obra qualificada, em períodos de rápidas transformações tecnológicas, sociais, políticas e econômicas, quando novas relações trabalhistas e estratégias surgem, empresas aguçando a competitividade do mercado, de forma que a organização estática acaba sendo atropelada pela avalanche de acontecimentos que impulsionam a sobreposição de um determinado seguimento sobre outros, resultando na falência de diversas delas em razão da não adaptação ao novo estilo de mercado globalizado, terceirizado e tecnológico ${ }^{9}$.

\section{Segundo ensina Maurício Godinho DELGADO:}

(...) terceirização é o fenômeno pelo qual se dissocia a relação econômica de trabalho da relação justrabalhista que Ihe seria correspondente. Por tal fenômeno insere-se o trabalhador no processo produtivo do tomador de serviços sem que se estendam a este os laços justrabalhistas, que se preservam fixados com uma entidade interveniente. A terceirização provoca uma relação trilateral em face da contratação de força de trabalho no mercado capitalista: o obreiro, prestador de serviços, que realiza suas atividades materiais e intelectuais junto à empresa tomadora de serviços; a empresa terceirizante, que contrata este obreiro, firmando com ele os vínculos jurídicos trabalhistas pertinentes; a empresa tomadora de serviços, eu concebe a prestação de labor, mas não assume a posição clássica de empregadora desse trabalhador envolvido ${ }^{10}$.

Por seu turno, e fazendo menção acerca da terceirização, Alice Monteiro de BARROS recomenda cautela na utilização do instituto em questão, e assim se posiciona:

Não acreditamos possa a terceirização constituir uma solução para todos os problemas empresariais. A terceirização requer cautela do ponto de vista econômico, pois implica planejamento de produtividade, qualidade e custos. Os cuidados devem ser redobrados do ponto de vista jurídico, porquanto a adoção de mão de obra terceirizada poderá implicar reconhecimento direto de vínculo empregatício com a tomadora de serviços, na hipótese de fraude, ou responsabilidade subsidiária dessa última, quando inadimplente a prestadora de serviços ${ }^{11}$.

\footnotetext{
${ }^{9}$ BATISTA, Lourival Lopes. Temas Aplicados de Direito do Trabalho \& Estudos de Direito Público. Organização e Coordenação de Jerônimo JESUS DOS SANTOS. São Paulo: LTr, 2012, p. 201.

${ }^{10}$ DELGADO, Maurício Godinho. Curso de Direito do Trabalho. São Paulo: LTr, 2011, p. 407. ${ }^{11}$ BARROS, Alice Monteiro de. Curso de Direito do Trabalho. 3. ed. rev. e ampl. São Paulo: LTr, 2007, p. 442.
} 
Para Maria Isabel Franco RIOS, e citando Eric Jhon HOBSBAWN, no artigo intitulado PL n. 1621/2007: Terceirização no Setor Privado e nas Sociedades de Economia Mista, o contexto da terceirização iniciou-se desde o século XVIII, no início da Revolução Industrial:

Informa-nos Eric Hobsbawn que desde o século XVIII, no início da Revolução Industrial, a terceirização já era uma realidade. Ela estava presente no sistema de putting out. Ocorria, na produção de artigos têxteis, confecção de vestuários e calçados. Era um sistema em que os mercadores deixavam as matérias-primas com os trabalhadores-artesãos que produziam em suas casas, com ferramentas próprias ou arrendadas e com a ajuda de auxiliares iniciantes. Estes produtos eram devolvidos aos mercadores que os comercializavam. Era um sistema que, além da valorização mercantil, permitia o aumento da superexploração do trabalho, utilizando-se do controle direto dos auxiliares, pois muitos artesãos recebiam incentivos para que seus colaboradores não se "dispersassem" no trabalho ${ }^{12}$.

Oportuno salientar que o Projeto de Lei citado por RIOS, dispõe sobre as relações de trabalho em atos de terceirização e na prestação de serviços a terceiros no setor privado e nas sociedades de economia mista.

Terceirização é, portanto, “o fenômeno através do qual um tomador de serviços transfere a outrem a contratação dos trabalhadores para a prestação de determinado serviço em proveito daquele" ${ }^{13}$.

No que pertine, ainda, à denominação do instituto da terceirização, Paulo Renato Fernandes da SILVA, assim se manifesta:

Não há uniformidade na denominação do instituo, cada autor destaca aspectos mais relevantes do mesmo. Nos EUA é comum a expressão outsourcing a designar algo fora (out) da origem (source), no sentido de buscar fora da empresa o auxílio de terceiros. No Brasil, a doutrina costuma denominar o fenômeno de subcontratação, subministração da mão de obra, horizontalização da empresa, marchandage, intemediação da mão de obra e terceirização (expressão também utilizada em Portugal) ${ }^{14}$.

\footnotetext{
12 RIOS, Maria Isabel Franco. PL 1.621/2007: Terceirização no Setor Privado e nas Sociedades de Economia Mista in O que há de Novo em Direito do Trabalho: Homenagem a Alice Monteiro de Barros e Antônio Álvares da Silva / Márcio Túlio Viana: coordenador - 2. ed. - São Paulo: LTr, 2012.

${ }^{13}$ SULZBACH, Lívia Deprá Camargo. A Responsabilização Subsidiária da Administração Pública na Terceirização de Serviços - Princípio da Supremacia do Interesse Público $X$ Dignidade da Pessoa Humana? - Repercussões do Julgamento da ADC n. 16 pelo STF na Súmula 331 do TST. In Revista LTr 76-06. p. 719, de junho de 2012.

${ }^{14}$ SILVA, Paulo Renato Fernandes da. Cooperativas de Trabalho, Terceirização de
}

Serviços e Direito do Trabalho. 2. ed. São Paulo: LTr, 2013, p. 77. 
Continua o mesmo autor, vindo a esclarece quais seriam os casos admitidos de terceirização do trabalho, e assim se posiciona:

Classificamos a terceirização em duas modalidades: a terceira típica (quando existir lei regulando aquela hipótese de trilateralização da relação de trabalho) e atípica (quando não existir lei específica regulando a hipótese de terceirização).

São os casos de terceirização típica:

a) Lei n. 12.690/12 (lei das sociedades cooperativas de trabalho);

b) Lei n. 6.019/74 (trabalho temporário);

c) Lei n. $7.102 / 83$ (segurança patrimonial);

d) Art. 429, CLT (aprendizado);

e) Lei n. 8630/93 (trabalhador avulso portuário, intermediado pelo OGMO);

f) Lei n. 12.023/09 (trabalhador avulso de movimentação de mercadorias em geral, intermediado pelo sindicato);

g) Lei n. 8.987/95 (lei geral que dispõe sobre o regime de concessão e permissão da prestação de serviços públicos, nos seu art. 25 , §§ $1^{a}$ permite a terceirização das atividades inerentes às exercidas pela concessionária);

h) Lei n. 9.472/97 (lei específica para o setor de telecomunicações, permite a terceirização nas atividades inerentes - art. 94, II);

i) Decreto-lei n. 200/67 (recomenda a terceirização de serviços no âmbito da administração pública).

Essas, portanto, são hipóteses de terceirização que se pode chamar de típicas, uma vez que previstas e autorizadas por lei. Mas a grande maioria dos casos de terceirização no país, não encontra tipificação em lei específica ou em lei geral.

Isto porque, ainda não há no Brasil uma lei geral (lei nacional) regulamentando o fenômeno da terceirização ${ }^{15}$.

Assim, abre-se espaço para o debate do fenômeno terceirização, seus apontamentos positivos e negativos, contudo, não se pode olvidar de sua real necessidade, e não se pode querer evitar sua efetivação não só em nosso País, mas num mundo globalizado, que urge por eficiência e celeridade.

\subsection{A TERCEIRIZAÇÃO NA ADMINISTRAÇÃO PÚBLICA - BREVES CONSIDERAÇÕES HISTÓRICAS}

A necessidade de contratação de serviços terceirizados mostra-se necessária, haja vista não haver condições mínimas do Poder Público, em

${ }^{15}$ Idem; p. 107-108. 
qualquer de suas esferas, de fazer frente à toda demanda de trabalho tão somente com o serviço efetivado por aqueles que devidamente prestaram concurso público, e o fizeram sob a égide do artigo 37, II, da Constituição Federal.

Neste sentido, e por mais que estejam se referindo no exemplo abaixo, de concessionárias do serviço público, os autores Indalécio GOMES NETO e Rider Nogueira de BRITO, assim esclarecem:

(...) devem se valer do concurso de terceiros, sejam pessoas físicas ou jurídicas, para a consecução dos seus objetivos. Diria mesmo que é impossível no estágio atual da economia mundial, das necessidades dos povos de todos os cantos do mundo, especialmente de um país como o nosso de proporções continentais e com usuários que se contam aos milhões e milhões, que essas empresas concessionárias pudessem cumprir com as suas obrigações contratadas com as várias esferas do poder público utilizando-se tão somente de pessoal próprio, por elas diretamente contratados. É tão impensável e tão inverossímil tal hipótese que raia o absurdo imaginar, e mais, exigir, que elas operassem somente com trabalhadores diretamente contratados, que não pudessem cometer grande parte das suas etapas de produção de serviços a terceiros, que não pudessem terceirizar suas atividades. Seriam empresas tão grandes e tão complexas que seriam inexoravelmente inadministráveis, ainda mais tendo em mente que se trata de serviço público, que atinge milhares, e não raro, milhões de pessoas, obras e serviços e volumes gigantescos, exigindo soluções rápidas, muitas vezes muito rápidas ${ }^{16}$.

Aponte-se também, e consoante ensina José Augusto Rodrigues PINTO, em seu artigo 'Por que ter medo da terceirização brasileira?', que há um temor intenso na utilização do instituto da terceirização, "em contraste com a firme adoção no contexto universal da sociedade tecnológica de nossa época"17. Ou seja, mesmo frente à necessidade de contratação face à demanda de serviço, ainda se constata temorosidade em sua efetivação.

De outra banda, Rodrigues PINTO, aponta que este temor não alcançou ao 'governo', como faz questão de firmar, senão veja-se:

O governo (e faço questão distingui-lo da noção abstrata do Estado) jamais temeu a terceirização. Vê-se isso na presteza com que assimilou a sua ideia no art. 10, § $7^{\circ}$, do já longínquo Decreto-lei n. 200, de 25.2.1967:

16 GOMES NETO, Indalécio; BRITO, Rider Nogueira. A Terceirização no Brasil. Curitiba: Íthala, 2012, p. 32-33.

17 PINTO, José Augusto Rodrigues. Por que ter medo da Terceirização Brasileira? In Revista LTr 75-11, p. 1304, de novembro de 2011. 
Art. 10. A execução das atividades da Administração Federal deverá ser amplamente descentralizada (destaques nossos).

$\S 7^{\circ}$. Para melhor desincumbir-se das tarefas de planejamento, coordenação, supervisão e controle e com o objetivo de impedir o crescimento desmesurado da máquina administrativa, a Administração procurará desobrigar-se da realização material de tarefas executivas, recorrendo, sempre que possível, à execução indireta, mediante contrato, desde que exista, na área, iniciativa privada suficientemente desenvolvida e capacitada a desempenhar os encargos da execução (destaques nossos) ${ }^{18}$.

A terceirização no setor público, que encontrou amparo jurídico primeiramente pelo Decreto-lei de $n^{\circ}$ 200/67, conforme acima enfatizado nas palavras de José Augusto Rodrigues PINTO e, atualmente, é regulamentada na Administração Pública Federal pelo Decreto $n^{0}$ 2.271/97, encontra divergências entre aqueles que a veem sob uma ótica administrativista, e os que a veem sob o prisma da proteção ao trabalhador.

Os que defendem a primeira posição entendem que se trata de instituto plenamente utilizável pela Administração Pública, haja vista, e como já foi visto, evita o inchaço da máquina pública, e a defesa encontra respaldo constitucional, consoante prescreve o artigo 37, XXI, da Constituição Federal ${ }^{19}$, o qual prevê a possibilidade de o ente público contratar serviços mediante licitação ${ }^{20}$.

Ainda em caminhada no contexto histórico, e anterior ao Decreto-lei e ao Decreto citados, a Lei n 4.320/64 já abordava a questão, não exatamente da terceirização em si, mas no tocante a despesas com serviços de terceiro. Esta lei, em seu art. 5º, preceitua o seguinte:

\footnotetext{
18 Idem; p. 1308.

19 Art. 37. A administração pública direta e indireta de qualquer dos Poderes da União, dos Estados, do Distrito Federal e dos Municípios obedecerá aos princípios de legalidade, impessoalidade, moralidade, publicidade e eficiência e, também, ao seguinte:

$(\ldots)$

XXI - ressalvados os casos especificados na legislação, as obras, serviços, compras e alienações serão contratados mediante processo de licitação pública que assegure igualdade de condições a todos os concorrentes, com cláusulas que estabeleçam obrigações de pagamento, mantidas as condições efetivas da proposta, nos termos da lei, o qual somente permitirá as exigências de qualificação técnica e econômica indispensáveis à garantia do cumprimento das obrigações.
}

(...)

20 SULZBACH, Lívia Deprá Camargo. Op. cit; p. 719. 
(...) a Lei de Orçamento não consignará dotações globais destinadas a atender indiferentemente a despesas de pessoal, material, serviços de terceiros, transferências de qualquer natureza ou quaisquer outras.

Cita-se novamente uma disposição do Decreto-Lei no 200/1967, que, em seu art. 10, § $7^{\circ}$, ainda mais enfatiza a necessidade da terceirização:

Para melhor desincumbir-se das tarefas de planejamento, coordenação, supervisão e controle e com o objetivo de impedir o crescimento desmesurado da máquina administrativa, a administração procurará desobrigar-se da realização material das tarefas executivas, recorrendo, sempre que possível, à execução indireta, mediante contrato, desde que exista, na área, iniciativa privada suficientemente desenvolvida e capacitada a desempenhar os encargos da execução.

Enfatize-se que foi o Decreto-Lei 200/67 o instrumento legal que forneceu a principal base jurídica para a terceirização no setor público.

No continuar da historização da terceirização de serviços junto à Administração Pública, tem-se a Lei $n^{\circ}$ 5.645/70, que veio a estabelecer as diretrizes para classificação de cargos do Serviço Civil da União e das autarquias federais; definiu que as atividades relacionadas com transporte, conservação, custódia, operação de elevadores, limpeza e outras assemelhadas seriam, de preferência, objeto de execução indireta (art. $3^{\circ}$, parágrafo único, posteriormente revogado pela Lei no 9.527, de 1997).

Já a atual Constituição Federal previu, em seu art. 37, inciso XXI, a possibilidade de contratação de serviços, pelo ente público, nos seguintes termos:

(...) ressalvados os casos especificados na legislação, as obras, serviços,compras e alienações serão contratados mediante processo de licitação pública que assegure igualdade de condições a todos os concorrentes, com cláusulas que estabeleçam obrigações de pagamento, mantidas as condições efetivas da proposta, nos termos da lei, o qual somente permitirá as exigências de qualificação técnica e econômicas indispensáveis à garantia do cumprimento das obrigações ${ }^{21}$.

Para o processo licitatório, então, fora editada a Lei nº 8.666/93 (Lei das Licitações), a qual previu a hipótese da contratação de serviços, desde que

\footnotetext{
${ }^{21}$ Disponível em: <http://www.planalto.gov.br/ccivil_03/constituicao/constituicao.htm> Acesso em: 26 mar. 2014.
} 
obedecidas às regras constantes de seu art. $7^{\circ}$, e seus incisos, bem como, e principalmente, em seu parágrafo $2^{\circ}$, que assim dispõem:

As licitações para a execução de obras e para a prestação de serviços obedecerão ao disposto neste artigo e, em particular, à seguinte sequência:

I - projeto básico;

II - projeto executivo;

III - execução das obras e serviços.

§ 2o As obras e os serviços somente poderão ser licitados quando:

I - houver projeto básico aprovado pela autoridade competente e disponível para exame dos interessados em participar do processo licitatório;

II - existir orçamento detalhado em planilhas que expressem a composição de todos os seus custos unitários;

III - houver previsão de recursos orçamentários que assegurem o pagamento das obrigações decorrentes de obras ou serviços a serem executadas no exercício financeiro em curso, de acordo com o respectivo cronograma;

IV - o produto dela esperado estiver contemplado nas metas estabelecidas no Plano Plurianual de que trata 0 art. 165 da Constituição Federal, quando for 0 caso $^{22}$.

Oportuno, aqui, fazer-se menção que a Lei 8.666/93, em seu inciso II do art. $6^{\circ}$, traz a definição de "serviços", qual seja: "toda atividade destinada a obter determinada utilidade de interesse para a Administração".

E, ainda mais importante no aspecto da contratação de terceiros, o citado estatuto prevê, consoante artigo 10:

Art. 10. As obras e serviços poderão ser executados nas seguintes formas:

I - execução direta;

II - execução indireta, nos seguintes regimes:

a) empreitada por preço global;

b) empreitada por preço unitário;

c) (Vetado).

d) tarefa;

e) empreitada integral.

Ou seja, a Lei de Licitações aponta quais serão os serviços desempenhados através de execução indireta; o que poderá, portanto, ser efetivado de forma terceirizada.

Com a entrada em vigor da Lei de Responsabilidade Fiscal (Lei Complementar $n^{\circ}$ 101/2000), novas orientações sobre a temática terceirização entraram em vigor. Podem ser citados dois dispositivos que versam direta ou indiretamente sobre as despesas no contexto da terceirização. Um deles, que

22 Disponível em: <http://www.planalto.gov.br/ccivil_03/leis//8666cons.htm> Acesso em 28 mar.2014. 
trata da classificação orçamentária das despesas relacionadas à terceirização, encontra-se no $\S 1^{\circ}$ do artigo 18:

(...) os valores dos contratos de terceirização de mão-de-obra que se referem à substituição de servidores e empregados públicos serão contabilizados como "Outras Despesas de Pessoal".

A terceirização na Administração Pública também tem sido disciplinada por normativos infralegais, tais como portarias, instruções normativas interministeriais e decisões de tribunais do Poder Judiciário.

\subsection{TERCEIRIZAÇÃO DE MÃO DE OBRA OU TERCEIRIZAÇÃO DE SERVIÇO?}

Abre-se espaço para a definição da efetiva possibilidade de terceirização junto à Administração Pública, se de terceirização de mão de obra ou de serviço. E como passa a ser demonstrado, há nítida diferença entre as contratações citadas, sendo que a contratação de mão de obra caminha de mãos dadas com a ilicitude.

O Decreto $n^{\circ} 2.271 / 97$, que dispõe sobre a contratação de serviços pela Administração Pública Federal direta, autárquica e fundacional e dá outras providências, prevê, em seu art. $3^{\circ}$ o que segue:

Art. $3^{\circ} \mathrm{O}$ objeto da contratação será definido de forma expressa no edital de licitação e no contrato exclusivamente como prestação de serviços.

$\S 1^{\circ}$ Sempre que a prestação do serviço objeto da contratação puder ser avaliada por determinada unidade quantitativa de serviço prestado, esta deverá estar prevista no edital e no respectivo contrato, e será utilizada como um dos parâmetros de aferição de resultados.

$\S 2^{\circ}$ Os órgãos e entidades contratantes poderão fixar nos respectivos editais de licitação, o preço máximo que se dispõem a pagar pela realização dos serviços, tendo por base os preços de mercado, inclusive aqueles praticados entre contratantes da iniciativa privada ${ }^{23}$.

Ou seja, necessário que o objeto da contratação da execução indireta de determinada atividade pelo setor público seja definido de forma expressa no edital de licitação e no contrato exclusivamente como prestação de serviços.

\footnotetext{
${ }^{23}$ Disponível em: <http://www.planalto.gov.br/ccivil_03/decreto/D2271.htm> Acesso em 26 mar.2014.
} 
E remetendo à questão de ilicitude, expressamente o artigo $4^{\circ}, 1 \mathrm{I}$, do Decreto em comento, veda a "inclusão de disposições nos instrumentos contratuais que permitam a caracterização exclusiva do objeto como fornecimento de mão-de-obra", sob pena de a terceirização ser considerada ilícita.

Nesta esteira, salutar o apontamento de Christian BEURLEN: “... o contrato de fornecimento de mão-de-obra é ilícito, e não pode ser firmado pela Administração Pública" ${ }^{24}$. Portanto, a terceirização de mão de obra é prática considerada ilícita e não se confunde com alocação de mão de obra, mormente terceirização de serviços.

Seguindo este entendimento, Antonieta Pereira VIEIRA, Henrique Pereira VIEIRA, Madeline Rocha FURTADO e Monique Rafaella Rocha FURTADO, referindo-se aos contratos de serviços terceirizados, definem que

A terceirização é um modelo de gestão em que a Administração contrata os serviços de terceiros (particulares), não podendo ser confundida com contratação de mão-de-obra ${ }^{25}$.

Terceirizar serviços, portanto, não significa contratar mão de obra, vindo os autores rejeitarem o conceito de terceirização como a simples contratação de mão de obra para executar tarefas definidas.

Essa discussão leva o gestor público a ter dificuldades em fazer distinção entre o contrato de fornecimento de mão de obra e o de prestação de serviços, "porque as diferenças são tênues". Esse é o entendimento de Maria Sylvia Zanella DI PIETRO ${ }^{26}$.

Em que pese, portanto, a proximidade dos contratos de fornecimento de mão de obra com os de prestação de serviços, essas duas modalidades não devem ser confundidas. Extrai-se que o contrato que tem por objeto 0

24 BEURLEN, Christian. A execução indireta de atividades da administração pública. Revista Zênite de Licitações e Contratos - ILC, n. 166, p. 1269-1273, dez. 2007, p. 3. Disponível em http://www.zenite.com.br. Acesso em 18 de março de 2014.

25 VIEIRA, Antonieta Pereira, VIEIRA, Henrique Pereira, FURTADO, Madeline Rocha, FURTADO, Monique Rafaella Rocha. Gestão de Contratos de Terceirização na Administração Pública: Teoria e Prática - Planilha de Custos - Formação de Preços e a sua Composição sob a ótica das instruções normativas do MPoG/Slti. 5. ed. rev. amp. São Paulo: Fórum, 2006, p. 123.

26 DI PIETRO, Maria Sylvia Zanella. Terceirização Municipal em face da Lei de Responsabilidade Fiscal. Revista Brasileira de Direito Municipal - RBDM, Belo Horizonte, $n$. 7, jan/mar.2003, p. 4. Disponível em http://www.editoraforum.com.br. Acesso em 10 de março de 2014. 
fornecimento de mão de obra é construído ao redor de sujeitos, enquanto que o prestação de serviços tem por sentido central a atividade realizada pelo contratado.

BERLEUN defende também a ideia de que, se em uma contratação estiverem presentes os elementos que configuram a relação de emprego (subordinação e pessoalidade), consoante dita o artigo $3^{\circ}$ da Consolidação das Leis do Trabalho ${ }^{27}$, caracterizada está a terceirização de mão de obra, conforme registrado a seguir:

Como se percebe, presentes os elementos materiais que configuram o contrato de trabalho, mesmo que ausente qualquer instrumento formal, a jurisprudência consolidada reconhece o vínculo empregatício, com todas as conseqüências daí advindas. Assim, mesmo que o contrato para execução indireta de atividades esteja firmado exclusivamente entre a pessoa jurídica contratante e a fornecedora de mão-de-obra, se restar configurada a relação de subordinação e pessoalidade com o trabalhador, tácita e direta será a relação de emprego deste com a tomadora de serviços. Quando o tomador é a Administração Pública, embora não se reconheça o vínculo formal, todas as demais responsabilidades podem ser a ela atribuídas de maneira subsidiária ou solidária ${ }^{28}$.

Conclui-se, então, que a contratação de fornecimento de mão de obra, caracterizada como sendo aquela em que estão presentes os requisitos, ou os elementos indicativos, de uma relação de subordinação e pessoalidade, é prática vedada tanto no setor privado como na Administração Pública, haja vista as disposições constantes do Enunciado $n^{\circ} 331 / 1993{ }^{29}$ e dos incisos II e

\footnotetext{
${ }^{27}$ Art. $3^{\circ}$ - Considera-se empregado toda pessoa física que prestar serviços de natureza não eventual a empregador, sob a dependência deste e mediante salário.

${ }^{28}$ BEURLEN, Christian. Op. cit, p. 3.

29 Consoante se extrai do site do TST, visualizado em 25.03.2014: http://www3.tst.jus.br/jurisprudencia/Sumulas_com_indice/Sumulas_Ind_301_350.html\#SUM-

331

Súmula $\mathrm{n}^{\circ} 331$ do TST

CONTRATO DE PRESTAÇÃO DE SERVIÇOS. LEGALIDADE (nova redação do item IV e inseridos os itens $V$ e VI à redação) - Res. 174/2011, DEJT divulgado em 27, 30 e 31.05 .2011

I - A contratação de trabalhadores por empresa interposta é ilegal, formando-Se o vínculo diretamente com o tomador dos serviços, salvo no caso de trabalho temporário (Lei $n^{\circ} 6.019$, de 03.01.1974).

II - A contratação irregular de trabalhador, mediante empresa interposta, não gera vínculo de emprego com os órgãos da Administração Pública direta, indireta ou fundacional (art. 37, II, da CF/1988).

III - Não forma vínculo de emprego com o tomador a contratação de serviços de vigilância (Lei $n^{0} 7.102$, de 20.06.1983) e de conservação e limpeza, bem como a de serviços especializados ligados à atividade-meio do tomador, desde que inexistente a pessoalidade e a subordinação direta.
} 
IV do art. $4^{\circ}$ do Decreto $n^{\circ} 2.271 / 1993$, consoante já exposto, sendo que, nesses casos, a terceirização é considerada ilícita.

\section{A TERCEIRIZAÇÃO DE SERVIÇO NA ADMINISTRAÇÃO PÚBLICA SOB A ÉGIDE DE CONVÊNIOS}

\subsection{DOS CONVÊNIOS, SEUS ASPECTOS LEGAIS, E APLICABILIDADE}

Ab initio, oportuno o apontamento ditado por Marçal JUSTEN FILHO, que, ao fazer menção sobre o que vem a ser o instituto convênio, assim se posiciona: "(...) avença em que dois ou mais sujeitos, sendo ao menos um deles integrante da Administração Pública, comprometem-se a atuar de modo conjugado para a satisfação de necessidades de interesse coletivo, sem intento de cunho lucrativo" 30 .

A Carta Magna fez menção ao convênio em dois de seus dispositivos: artigo 71, inciso VI e artigo 199, § $1^{0} 31$.

Os convênios genuinamente públicos, fundamentam-se na efetivação do federalismo de cooperação consagrado pela Constituição (artigos 23 e 241)

IV - O inadimplemento das obrigações trabalhistas, por parte do empregador, implica a responsabilidade subsidiária do tomador dos serviços quanto àquelas obrigações, desde que haja participado da relação processual e conste também do título executivo judicial.

$\mathrm{V}$ - Os entes integrantes da Administração Pública direta e indireta respondem subsidiariamente, nas mesmas condições do item IV, caso evidenciada a sua conduta culposa no cumprimento das obrigações da Lei n. ${ }^{\circ}$ 8.666, de 21.06.1993, especialmente na fiscalização do cumprimento das obrigações contratuais e legais da prestadora de serviço como empregadora. A aludida responsabilidade não decorre de mero inadimplemento das obrigações trabalhistas assumidas pela empresa regularmente contratada.

VI - A responsabilidade subsidiária do tomador de serviços abrange todas as verbas decorrentes da condenação referentes ao período da prestação laboral.

30 JUSTEN FILHO, Marçal. Op. cit, p. 422.

${ }^{31}$ Art. 71. O controle externo, a cargo do Congresso Nacional, será exercido com o auxílio do Tribunal de Contas da União, ao qual compete:

(...)

VI - fiscalizar a aplicação de quaisquer recursos repassados pela União mediante convênio, acordo, ajuste ou outros instrumentos congêneres, a Estado, ao Distrito Federal ou a Município;

(...)

Art. 199. A assistência à saúde é livre à iniciativa privada.

$\S 1^{\circ}$ - As instituições privadas poderão participar de forma complementar do sistema único de saúde, segundo diretrizes deste, mediante contrato de direito público ou convênio, tendo preferência as entidades filantrópicas e as sem fins lucrativos.

(...). Acesso em 26.03.2014, através do site: http://www.jusbrasil.com.br/topicos/10653066/artigo-199-da-constituicao-federal-de-1988 
32, em especial após o advento da E. C. no 19/98, o qual modificou "o regime e dispõe sobre princípios e normas da Administração Pública, servidores e agentes políticos, controle de despesas e finanças públicas e custeio de atividades a cargo do Distrito Federal, e dá outras providências" ${ }^{33}$.

Art. 23. É competência comum da União, dos Estados, do Distrito Federal e dos Municípios:

I - zelar pela guarda da Constituição, das leis e das instituições democráticas e conservar o patrimônio público;

II - cuidar da saúde e assistência pública, da proteção e garantia das pessoas portadoras de deficiência;

III - proteger os documentos, as obras e outros bens de valor histórico, artístico e cultural, os monumentos, as paisagens naturais notáveis e os sítios arqueológicos;

IV - impedir a evasão, a destruição e a descaracterização de obras de arte e de outros bens de valor histórico, artístico ou cultural;

$\mathrm{V}$ - proporcionar os meios de acesso à cultura, à educação e à ciência;

$\mathrm{VI}$ - proteger o meio ambiente e combater a poluição em qualquer de suas formas;

VII - preservar as florestas, a fauna e a flora;

VIII - fomentar a produção agropecuária e organizar o abastecimento alimentar;

IX - promover programas de construção de moradias e a melhoria das condições habitacionais e de saneamento básico;

$\mathrm{X}$ - combater as causas da pobreza e os fatores de marginalização, promovendo a integração social dos setores desfavorecidos;

$\mathrm{XI}$ - registrar, acompanhar e fiscalizar as concessões de direitos de pesquisa e exploração de recursos hídricos e minerais em seus territórios;

XII - estabelecer e implantar política de educação para a segurança do trânsito.

Parágrafo único. Lei complementar fixará normas para a cooperação entre a União e os Estados, o Distrito Federal e os Municípios, tendo em vista o equilíbrio do desenvolvimento e do bem-estar em âmbito nacional.

Parágrafo único. Leis complementares fixarão normas para a cooperação entre a União e os Estados, o Distrito Federal e os Municípios, tendo em vista o equilíbrio do desenvolvimento e do bem-estar em âmbito nacional. (Redação dada pela Emenda Constitucional n 53, de 2006)

Art. 241. A União, os Estados, o Distrito Federal e os Municípios disciplinarão por meio de lei os consórcios públicos e os convênios de cooperação entre os entes federados, autorizando a gestão associada de serviços públicos, bem como a transferência total ou parcial de encargos, serviços, pessoal e bens essenciais à continuidade dos serviços transferidos. (Redação dada pela Emenda Constitucional n 19, de 1998).

${ }^{32}$ Acesso em 26.03.2014, através do site: http://www.jusbrasil.com.br/topicos/10642366/artigo241-da-constituicao-federal-de-1988.

${ }_{33}$ Disponível em: <http://www.planalto.gov.br/ccivil_03/constituicao/Emendas/Emc/emc19.htm> Acesso em 28 mar.2014. 
No contexto acerca do acima citado federalismo cooperativo, em consonância com o aspecto da cooperação material no plano interno, imperioso o ensinamento de Marcos Augusto MALISKA, que assim se aponta:

A cooperação material no plano interno compreende todas as formas de parcerias entre o poder público e a sociedade visando atingir uma finalidade de interesse público. Ela reflete tanto o engajamento pessoal quanto institucional na participação da organização e da realização de direitos fundamentais prestacionais. Nesse sentido se aponta que interesse público não é um monopólio estatal, pois por público se tem um conceito mais amplo, que vai muito além da ideia de pertencimento estatal. Em contraposição, à ideia de cooperação normativa, a cooperação material é muito mais ampla, pois se encontra no campo das ações concretas que de inúmeras formas e modelos podem ser executadas com a participação da sociedade ${ }^{34}$.

Nesta caminhada cultural ensinada por MALISKA, vem este professor a citar Marçal JUSTEN FILHO, posicionando os convênios como manifestações do dever de colaboração:

Tratando da ordem constitucional brasileira, Justen Filho escreve que "os convênios são manifestações do dever de colaboração entre os entres estatais, entre si ou com a sociedade civil. O art. 241 da CF/88 incentiva a sua prática.". JUSTEN FILHO, Marçal. Comentários à Lei de licitações e contratos administrativos. 14. ed. São Paulo: Dialética, 2010, p. $953^{35}$.

Finalmente, e ainda com base nos apontamentos de MALISKA, este remete 0 federalismo cooperativo ao andar em sintonia com 0 constitucionalismo social:

O federalismo cooperativo apresentou-se, de certa forma, com a resposta do federalismo aos desafios do Estado social. Enquanto que o chamado federalismo dual era identificado com o Estado liberal, o federalismo cooperativo em sintonia com o constitucionalismo social do século XX buscou desencadear mecanismos de cooperação regional visando à superação das desigualdades espaciais ${ }^{36}$.

\footnotetext{
${ }^{34}$ MALISKA, Marcos Augusto. Fundamentos da Constituição: Abertura - Cooperação Integração. Curitiba: Juruá, 2013, p. 89.

${ }^{35}$ Idem; p. 89-90.

${ }^{36}$ Idem; p. 90.
} 
Mostra-se, portanto, que além da necessidade de se fazer frente à demanda de serviços, há as questões defendidas por MALISKA, que tratam da cooperação material, do federalismo cooperativo e o constitucionalismo social, que devem caminhar no mesmo diapasão.

Não se pode olvidar, contudo, e como já defendido anteriormente, que os convênios celebrados com entidades privadas devem garantir que 0 interesse público seja protegido.

Novamente se destaca o fato de que nenhuma esfera da Administração Pública brasileira detém a autossuficiência no tocante a produzir diretamente todos os bens, serviços e obras de que necessita para cumprir com suas atribuições.

O ordenamento jurídico brasileiro apresenta algumas inovações acerca das espécies de vínculos que podem existir entre uma entidade administrativa e terceiros. As duas mais conhecidas são os contratos e os convênios. Por seu turno, o convênio não se confunde com as contratações administrativas em sentido restrito, segundo assinala Marçal JUSTEN FILHO:

Em primeiro lugar, o convênio é um contrato associativo, de cunho organizacional. Isso significa que a prestação realizada por uma das partes não destina a ser incorporada no patrimônio da outra. As partes do convênio assumem direitos e obrigações visando à realização de um fim comum. Diversamente se passa com a maioria dos contratos administrativos, que apresentam cunho comutativo: as partes se valem da contratação para produzir a transferência entre si da titularidade de bens e interesses.

Essa distinção se relaciona com o posicionamento recíproco entre as partes. No convênio, as partes não percebem remuneração por atuação e todos os recursos são aplicados no desempenho de uma atividade de relevância coletiva. Nos demais contratos administrativos, o usual é a existência de interesses contrapostos, existindo interesse lucrativo pelo menos de uma das partes (o particular).

Outra distinção reside em que os contratos administrativos comportam, usualmente, apenas duas partes. Já os convênios podem ser integrados por um número superior de pares, à semelhança do que se passa com os contratos associativos no direito privado ${ }^{37}$.

No convênio, conforme compreendido no Direito Público, o objetivo é o de realizar determinado interesse comum, em prol da coletividade. O espírito aqui é o da mútua colaboração ou da cooperação, conforme já esclarecido quando da citação de MALISKA.

\footnotetext{
${ }^{37}$ JUSTEN FILHO, Marçal. Op.cit, p. 422-423.
} 
Podem-se citar como exemplo de contrato de convênio, os celebrados para a terceirização dos serviços de saúde. Nesta senda, o artigo 24 da Lei no 8.080/9038, ao admitir que o Sistema único de Saúde possa recorrer aos serviços ofertados pela iniciativa privada, ou seja, daqueles ofertados pela capacidade instalada desta, prevê, no seu parágrafo único, que a utilização de tais serviços privados "será formalizada mediante contrato ou convênio, observadas, a respeito, as normas de direito público".

Diante, portanto, de tudo que exposto, é patente que a celebração de um convênio, remete à caracterização de uma relação de direito administrativo e não de direito de trabalho.

Cite-se, igualmente, a possibilidade de se firmar convênio, quando da análise da Lei $n^{\circ}$ 9.637/98, no que se refere, em especial, à saúde pública. Tal dispositivo legal, "dispõe sobre a qualificação de entidades como organizações sociais, a criação do Programa Nacional de Publicização, a extinção dos órgãos e entidades que menciona e a absorção de suas atividades por organizações sociais, e dá outras providências" ${ }^{39}$. Nesta esteira, também o artigo $7^{\circ}$ da Lei n 8.080/990, vem especificar que as ações e serviços públicos de saúde devem obedecer, entre outros, princípio da descentralização políticoadministrativa ${ }^{40}$.

\footnotetext{
38 Art. 24. Quando as suas disponibilidades forem insuficientes para garantir a cobertura assistencial à população de uma determinada área, o Sistema Único de Saúde (SUS) poderá recorrer aos serviços ofertados pela iniciativa privada.

Parágrafo único. A participação complementar dos serviços privados será formalizada mediante contrato ou convênio, observadas, a respeito, as normas de direito público. Disponível em: <http://conselho.saude.gov.br/legislacao/lei8080.htm> Acesso em: 26 mar. 2014.

39 Disponível em: <http://www.planalto.gov.br/Ccivil_03/LEIS/L9637.htm> Acesso em 28 mar.2014.

${ }^{40}$ Lei $n^{\circ} 8.080$ de 19 de Setembro de 1990

Dispõe sobre as condições para a promoção, proteção e recuperação da saúde, a organização e o funcionamento dos serviços correspondentes e dá outras providências.

Art. $7^{\circ}$ As ações e serviços públicos de saúde e os serviços privados contratados ou conveniados que integram o Sistema Único de Saúde (SUS), são desenvolvidos de acordo com as diretrizes previstas no art. 198 da Constituição Federal, obedecendo ainda aos seguintes princípios:

I - universalidade de acesso aos serviços de saúde em todos os níveis de assistência;

II - integralidade de assistência, entendida como conjunto articulado e contínuo das ações e serviços preventivos e curativos, individuais e coletivos, exigidos para cada caso em todos os níveis de complexidade do sistema;

III - preservação da autonomia das pessoas na defesa de sua integridade física e moral;

IV - igualdade da assistência à saúde, sem preconceitos ou privilégios de qualquer espécie;

V - direito à informação, às pessoas assistidas, sobre sua saúde;
} 


\subsection{ISONOMIA DE TRATAMENTO E ISONOMIA SALARIAL}

No que pese o serviço desempenhado por aqueles trabalhadores que advém da empresa conveniada, e que o fazem na maior parte das vezes com a mesma perfeição daqueles concursados, tal fato não remete à necessidade de isonomia salarial. Isto, evidentemente, não distorce a igualdade de tratamento que deve ser dada ao trabalhador que é inserido no âmbito da administração pública por força de convênios. Até mesmo porque, muito além do trabalhador, existe um ser humano a quem deve ser direcionado todo respeito e reconhecimento pelo seu exercício laboral.

Portanto, a isonomia salarial não pode prosperar. Isto porque se está a caracterizar a figura do convênio, que vêm disciplinado pelos artigos 71, VI, e 199, $\S 1^{\circ}$, ambos da Constituição Federal, conforme anteriormente aduzido. Além disto, outros dispositivos, consoante também já demonstrado, denotam a relação de cooperação, em perfeito procedimento de natureza administrativa e não de relação contratual.

Neste sentido, e citando Alberto Shinji HIGA, fica ainda mais clara a questão da necessidade de cooperação através de convênios, não se podendo falar em isonomia salarial naquilo que a lei não previu:

Com o advento da EC no 19/98, foi alterada a redação do art. 241 para determinar a disciplina, por lei, dos consórcios públicos e dos convênios de cooperação entre os entes políticos, autorizando a gestão associada de serviços públicos, bem como a transferência total ou parcial de encargos, serviços, pessoal e bens especiais á continuidade dos serviços transferidos.

VI - divulgação de informações quanto ao potencial dos serviços de saúde e a sua utilização pelo usuário;

VII - utilização da epidemiologia para o estabelecimento de prioridades, a alocação de recursos e a orientação programática;

VIII - participação da comunidade;

IX - descentralização político-administrativa, com direção única em cada esfera de governo:

a) ênfase na descentralização dos serviços para os municípios;

b) regionalização e hierarquização da rede de serviços de saúde;

X - integração em nível executivo das ações de saúde, meio ambiente e saneamento básico;

$\mathrm{XI}$ - conjugação dos recursos financeiros, tecnológicos, materiais e humanos da União, dos Estados, do Distrito Federal e dos Municípios na prestação de serviços de assistência à saúde da população;

XII - capacidade de resolução dos serviços em todos os níveis de assistência; e

XIII - organização dos serviços públicos de modo a evitar duplicidade de meios para fins idênticos. Disponível em: <http://www.jusbrasil.com.br/topicos/11676999/artigo-7-da-lei-n-8080de-19-de-setembro-de-1990> Acesso em 28 mar.2014. 
A referida EC n 19/98 alterou ainda a redação do $\$ 2^{\circ}$ do art. 39 para constar a possibilidade de celebração de convênios ou contratos entre os entes federados, no que toca à manutenção de escolas de governo para a formação e o aperfeiçoamento dos servidores públicos ${ }^{41}$.

\subsection{DAS DECISÕES DOS TRIBUNAIS}

Para fundamentar o que foi exposto até o momento, e de forma a traduzir o entendimento dos Tribunais nacionais, passa-se a colecionar alguns julgados, conforme seguem.

(Doc LEGJUR 136.7681.6003.9100)

TRT 3 Região - Servidor celetista. Isonomia salarial. Isonomia salarial. Empregado celetista e servidor público. Impossibilidade.

«A par da alegada igualdade de funções, não se pode assegurar isonomia salarial a relações estabelecidas em condições distintas, sendo uns de natureza administrativa, em que o empregador, órgão público, deve cumprir seu quadro de carreira, submetido ao regime estatutário e à Lei 8.112/90, e o outro, contrato de trabalho firmado com o particular, regido pela CLT. Impossível falar de isonomia de situações tão díspares, entre os empregados da primeira reclamada e os servidores (...) ${ }^{42}$.

TRT-10 - RECURSO ORDINARIO RO 417200700910000 DF 00417-2007009-10-00-0 (TRT-10)

Data de publicação: 11/04/2008

Ementa: RESPONSABILIDADE SUBSIDIÁRIA. IMPOSSIBILIDADE. INEXISTÊNCIA DE TERCEIRIZAÇÃO DE SERVIÇOS. CONVÊNIO ADMINISTRATIVO. INTERESSE SOCIAL. Evidenciado nos autos a regular formação de convênio administrativo entre as Reclamadas, consistente na mútua cooperação entre os partícipes, objetivando a consecução de interesses comuns e convergente, em atenção à regra contida no art. 227 da Constituição Federal, e visando a execução de serviços de interesse social, há de ser afastada a hipótese de intermediação de mão-de-obra, impedindo, assim, a aplicação da Súmula 331 do col. TST, e a conseqüente responsabilização subsidiária do Distrito Federal. Recurso conhecido e parcialmente provido.

TRT-10 - RECURSO ORDINARIO RO 227200700810006 DF 00227-2007008-10-00-6 (TRT-10)

Data de publicação: 18/04/2008

Ementa: NULIDADE DO CONTRATO DE TRABALHO. ENTE PÚBLICO. ART. 37 , Il e $\S 2^{\circ}$, DA CF/88 . A jurisprudência consolidou-se no sentido de que: "A contratação de servidor público após a CF/1988 sem prévia aprovação em concurso público, encontra óbice no respectivo art. 37 , II e $\S 2^{\circ}$, somente lhe conferindo direito ao pagamento da contraprestação pactuada em relação ao

\footnotetext{
${ }^{41}$ HIGA, Alberto Shinji. Terceiro Setor: Da Responsabilidade Civil do Estado e do Agente Fomentado. Belo Horizonte: Fórum, 2010, p. 169.

${ }^{42}$ Disponível em: <http://www.legjur.com/jurisprudencia/eme/136.7681.6003.9100> Acesso em 28 mar.2014.
} 
número de horas trabalhadas, respeitado o valor da hora do salário mínimo, e dos valores referentes aos depósitos do FGTS". (Súmula no 363/TST.) Recurso da Reclamante conhecido e não provido. RESPONSABILIDADE SUBSIDIÁRIA. IMPOSSIBILIDADE. INEXISTÊNCIA DE TERCEIRIZAÇÃO DE SERVIÇOS. CONVÊNIO ADMINISTRATIVO. INTERESSE SOCIAL. Evidenciado nos autos a regular formação de convênio administrativo entre as Reclamadas, consistente na mútua cooperação entre os partícipes, visando a consecução de interesses comuns e convergentes, e visando a execução de serviços de interesse social, em atenção à regra contida no art. 227 da Constituição Federal, há de ser afastada a hipótese de intermediação de mão-de-obra, impedindo, assim, a aplicação da Súmula 331 do col. TST, e a conseqüente responsabilização subsidiária do Distrito Federal. Recurso Ordinário do $2^{\circ}$ Reclamado conhecido e provido.

Oportuno também argumentar, que mesmo quando eventualmente, e de alguma forma a decisão do Tribunal vem imputar alguma responsabilidade na relação havida com terceiro à Administração Pública, também, não haveria que se falar em vínculo empregatício com esta:

TERCEIRIZAÇÃO. CONVÊNIO. RESPONSABILIDADE SUBSIDIÁRIA DO TOMADOR DE SERVIÇO. ÓRGÃO DA ADMINISTRAÇÃO PÚBLICA.

A contratação de mão-de-obra, sob a forma de convênio, revela-se como um artifício que visa burlar a imposição de concurso público para admissão de empregados e dispensar a realização de licitação. Ademais, tratando-se de atividade típica de servidor público, identifica-se de forma clara a terceirização ilegal. Todavia, sendo o tomador de serviços um órgão da Administração Pública, inviabilizado está o reconhecimento do vínculo empregatício direto com este. Entretanto, permanecem resguardados os direitos do trabalhador, diante de eventual inadimplência da empresa interposta, por meio da imposição da responsabilidade subsidiária do tomador de serviços pelo crédito reconhecido judicialmente. Incidência do entendimento consubstanciado na Súmula $\mathrm{n}^{\circ} 331$, do Colendo TST e na Súmula $\mathrm{n}^{\circ} 1$ do Egrégio TRT da 1ª Região. (Processo RO 913820115010039 RJ. Relator(a) Rogerio Lucas Martins. Julgamento: 10/04/2012. Órgão Julgador: Nona Turma. Publicação em 2012-04-13).

Entende-se, ainda, que sequer pode-se falar em aplicação do Enunciado 363 do TST, que assim dispõe:

Enunciado n. 363 - Contrato Nulo. Efeitos. A contratação de servidor público, após a CF/1988, sem prévia aprovação em concurso público, encontra óbice no respectivo art. 37 , II e $\S 2^{\circ}$, somente lhe conferindo direito ao pagamento da contraprestação pactuada, em relação ao número de horas trabalhadas, respeitado o valor da hora do salário mínimo, e dos valores referentes aos depósitos do FGTS.

Isto porque, e mais uma vez frise-se, está-se falando em "convênio" e não de contratos administrativos, fugindo, por conseguinte, ao aplicativo acima. 
Cite-se, também, no mesmo contexto da impossibilidade de isonomia salarial, a Orientação Jurisprudencial número 297, do Tribunal Superior do Trabalho, que assim disciplina:

OJ n. 297, SDI - 1. Equiparação salarial. Servidor público da administração direta, autárquica e fundacional. Art. 37, XIII, da CF/1988. O art. 37, inciso XIII, da CF/1988, veda a equiparação de qualquer natureza para o efeito de remuneração do pessoal do serviço público, sendo juridicamente impossível a aplicação da norma infraconstitucional prevista no art. 461 da CLT quando se pleiteia equiparação salarial entre servidores públicos, independentemente de terem sido contratados pela CLT.

Vê-se, portanto, que não se concebe falar em isonomia salarial quando em análise o concursado com o trabalhador que venha somar, em cooperação, através de convênios.

TRT/MG - ISONOMIA SALARIAL. EMPREGADO CELETISTA E SERVIDOR PÚBLICO.

Data da publicação da decisão - 09/03/2012.

Processo: 5. 0001863-22.2010.5.03.0134 RO(01863-2010-134-03-00-3 RO)

Órgão Julgador: Primeira Turma

Relator: Emerson Jose Alves Lage

Revisor: Convocada Monica Sette Lopes

Vara de Origem: 5a. Vara do Trabalho de Uberlândia

Publicação: 09/03/2012

Divulgação: 08/03/2012. DEJT. Página 125. Boletim: Não.

EMENTA: ISONOMIA SALARIAL. EMPREGADO CELETISTA E SERVIDOR PÚBLICO.

A par da alegada igualdade de funções, não se pode assegurar isonomia salarial a contratos firmados em condições distintas, sendo um de natureza administrativa, em que o empregador, órgão público, deve cumprir seu quadro de carreira, submetido ao regime estatutário e à Lei 8.112/90, e o outro, contrato de trabalho firmado com o particular, regido pela CLT ${ }^{43}$.

Desta forma, não se pode olvidar do verdadeiro sentido dos convênios, que buscam a harmonia e cooperação dentre o chamado federalismo cooperativo. Em sendo assim, e calcado na legislação pátria, bem como, em decisões judiciais, a isonomia salarial não se aplica a casos de celebração de convênios, quando comparados funcionários concursados com aqueles cedidos pela conveniada. 


\section{CONCLUSÃO}

Contratos de Terceirização devem ser adequadamente elaborados sob a égide da legislação aplicável à espécie, para que não recaia o instituto da terceirização em ilicitude. O que deve ser buscado é tornar caracterizada a contratação de serviços e não de pessoas, minimizando-se os riscos de eventuais demandas trabalhistas e responsabilidades solidárias para o ente contratante.

Considera-se, portando, a Terceirização uma ferramenta gerencial necessária, contudo, sempre deve estar em consonância com nossa legislação, e princípios que norteiam a administração pública.

Assim, impõe-se a exigência de ratificar o mecanismo como peça componente do planejamento de qualquer empresa, pública ou privada, por seu turno, inibir práticas deletérias, que se mostrem à margem da lei.

Importante para a celebração dos convênios, que estes estejam calcados em princípios que norteiam a administração pública.

E no encerramento do presente, externa-se a convicção de que o instituto da Terceirização não representa um dragão a ser domado, mas apenas um gigante que precisa encontrar o seu caminho.

Finalmente, o convênio é sim bem-vindo, e mais que isto, necessário na consecução e aperfeiçoamento da máquina pública, contudo, isto não implica necessariamente dizer que deva haver isonomia salarial entre 0 concursado e trabalhador não concursado, que venha a desempenhar suas atividades junto à administração pública.

\section{REFERÊNCIAS}

BARROS, Alice Monteiro de. Curso de Direito do Trabalho. 3 ed. rev. e ampl. São Paulo: LTr, 2007.

BATISTA, Lourival Lopes. Temas Aplicados de Direito do Trabalho \& Estudos de Direito Público. Org. Jerônimo Jesus dos Santos. São Paulo: LTr, 2012. 
BEURLEN, Christian. A execução indireta de atividades da administração pública. Revista Zênite de Licitações e Contratos - ILC, n. 166, p. 1269-1273, dez. 2007. Disponível em http://www.zenite.com.br. Acesso em 18 de março de 2014.

DELGADO, Maurício Godinho. Curso de Direito do Trabalho. São Paulo: LTr, 2011.

DI PIETRO, Maria Sylvia Zanella. Direito administrativo. 25 ed. São Paulo: Atlas, 2012.

- Terceirização Municipal em face da Lei de Responsabilidade Fiscal. Revista Brasileira de Direito Municipal - RBDM, Belo Horizonte, n. 7, jan/mar.2003. Disponível em http://www.editoraforum.com.br. Acesso em 10 de março de 2014.

GOMES NETO, Indalécio; BRITO, Rider Nogueira. A Terceirização no Brasil. Curitiba: Íthala, 2012.

HIGA, Alberto Shinji. Terceiro Setor: Da Responsabilidade Civil do Estado e do Agente Fomentado. Belo Horizonte: Fórum, 2010, p. 169.

JUSTEN FILHO, Marçal. Curso de Direito Administrativo. 8. ed. rev. amp. e atual. Belo Horizonte: Fórum, 2012. p. 225-226.

MEIRELLES, Hely Lopes. Direito Administrativo Brasileiro. 27 ed. São Paulo: Malheiros, 2002.

MIRAGEM, Bruno. A Nova Administração Pública e o Direito Administrativo. 2 ed. rev. e atual. São Paulo: Revista dos Tribunais, 2013.

MIRANDA, Jorge. Manual de Direito Constitucional, Tomo IV: Direitos Fundamentais. Coimbra: Coimbra, 2000.

PINTO, José Augusto Rodrigues. Por que ter medo da Terceirização Brasileira? In Revista LTr 75-11, novembro de 2011.

RIOS, Maria Isabel Franco. PL 1.621/2007: Terceirização no Setor Privado e nas Sociedades de Economia Mista in O que há de Novo em Direito do Trabalho: Homenagem a Alice Monteiro de Barros e Antônio Álvares da Silva / Márcio Túlio Viana: coordenador - 2 ed. - São Paulo: LTr, 2012.

ROSA, Márcio Fernando Elias. Direito Administrativo, Parte I. Coleção Sinopses Jurídicas, v. 19, Saraiva, 2010.

SILVA, José Afonso da. Curso de Direito Constitucional Positivo. 21 ed. São Paulo: Malheiros, 2002. 
SILVA, Paulo Renato Fernandes da. Cooperativas de Trabalho, Terceirização de Serviços e Direito do Trabalho. 2 ed. São Paulo: LTr, 2013. SULZBACH, Lívia Deprá Camargo. A Responsabilização Subsidiária da Administração Pública na Terceirização de Serviços - Princípio da Supremacia do Interesse Público $X$ Dignidade da Pessoa Humana? Repercussões do Julgamento da ADC n. 16 pelo STF na Súmula 331 do TST. In Revista LTr 76-06, junho de 2012.

VIEIRA, Antonieta Pereira, VIEIRA, Henrique Pereira, FURTADO, Madeline Rocha, FURTADO, Monique Rafaella Rocha. Gestão de Contratos de Terceirização na Administração Pública: Teoria e Prática - Planilha de Custos - Formação de Preços e a sua Composição sob a ótica das instruções normativas do MPoG/Slti. 5 ed. rev. amp. São Paulo: Fórum, 2006. 